\title{
Family Support on the Adherence to Nutrition Intake among Adults with Primary Hypertension in Kalanganyar, Lebak, Banten, Indonesia
}

\author{
Chandra Tri Wahyudi, Arief Wahyudi Jadmiko, Ritanti
}

Faculty of Health Science, Universitas Pembangunan Nasional Veteran Jakarta, Indonesia

\section{ABSTRACT}

Background: An example of hypertension management is compliance with the management of nutritional needs according to the hypertension dietary guidelines. Adherence to a hypertension diet can be influenced by family support. In Kalanganyar, Lebak, Banten, Indonesia, there is a phenomenon that many hypertension patients' are less compliant with dietary management and allegedly due to lack of family support. This study aimed to examine the family support on the adherence to nutrition intake in primary hypertension patients.

Subjects and Method: This was a cross sectional study conducted in Kalanganyar, Lebak, Banten, Indonesia. A total of 174 adults with primary hypertension was selected for this study. The dependent variable was Adherence to Nutrition intake. The independent variables were age, gender, level of education, duration of hypertension, and family support. The data were collected by questionnaire and analyzed using a multiple logistic regression.

Results: Adherence to nutrition intake among hypertension patients increased with female
$(\mathrm{OR}=2.46 ; 95 \% \mathrm{CI}=1.19$ to $5.14 ; \mathrm{p}=0.016), \operatorname{good}$ family support $(\mathrm{OR}=2.92 ; 95 \% \mathrm{CI}=1.50$ to 5.70 ; $\mathrm{p}=0.002)$, and acute hypertension $(\mathrm{OR}=2.41$; $95 \% \mathrm{CI}=1.18$ to $4.94 ; \mathrm{p}=0.015)$. Older age $(\mathrm{OR}=$ $0.31 ; 95 \% \mathrm{CI}=0.21$ to $4.65 ; \mathrm{p}=0.398)$ and low education $(\mathrm{OR}=2.00 ; 95 \% \mathrm{CI}=0.43$ to $9.35 ; \mathrm{p}=$ 0.375) were not statistically associated with adherence to nutrition intake among hypertensive patients.

Conclusion: Adherence to nutrition intake among adults with primary hypertension was associated with gender, supportive family, and period of hypertension.

Keywords: hypertension, nutrition intake, family support

\section{Correspondence:}

Chandra Tri Wahyudi. Faculty of Health Science, Universitas Pembangunan Nasional Veteran Jakarta. Jl. Limo Raya, Kota Depok. Email: chan.tw.1987@gmail.com. Mobile: +628-2299481234

\section{Cite this as:}

Wahyudi CT, Jadmiko AW, Ritanti (2020). Family support on the adherence to nutrition intake among adults with primary hypertension in Kalanganyar, Lebak, Banten, Indonesia. J Epidemiol Public Health. 05(02): 132140. https://doi.org/10.26911/jepublichealth.2020.05.02.01

(ic) Journal of Epidemiology and Public Health is licensed under a Creative Commons (c) ${ }_{\text {EY NC SA }}$ Attribution-Non Commercial-Share Alike 4.o International License.

\section{BACKGROUND}

As a disease whose prevalence is quite high in Indonesia and even in the world, hypertension is a separate burden that must be controlled by management in the community. An important component is diet management, which maintaining normal blood pressure, achieving and maintaining normal serum lipid levels, providing enough energy to achieve normal body weight, managing or avoid- ing acute complications of patients and improving overall health status through optimal nutrition. However, at present many hypertension sufferers do not comply with the recommended diet due to lack of knowledge and awareness of patients about hypertension (Rosyid and Efendi, 2011).

In 2015, the World Health Organization (WHO) stated that around 1.13 billion people worldwide suffer from hypertension and $2 / 3$ 
Wahyudi et al./ Family support on the adherence to nutrition intake in primary hypertension

of them are in developing countries. Furthermore, WHO also predicts that the incidence of hypertension continues to rise sharply and in 2025 around $29 \%$ of adults worldwide are estimated to be affected by hypertension. Statistics at the national level are no less worrisome.

The basic health research data (Riskesdas) shows the prevalence of hypertension in 2018 based on the results of measurements of population aged $>18$ years which tends to increase, namely $25.8 \%$ in 2013 and $34.1 \%$ in 2018 (Ministry of Health, 2018). Among many provinces in Indonesia, Banten is one of the provinces that has a high incidence of hypertension. Banten is ranked $15^{\text {th }}$ most populous province with hypertension based on doctor's diagnosis. In fact, based on measurement criteria, the incidence of hypertension in the province reaches almost $30 \%$ (close to the national average of 34.1\%) (Ministry of Health, 2018).

Preliminary studies conducted by researchers in the Kalanganyar region, Lebak, Banten in May 2019 involving 3 people with adult hypertension showed that there was only 1 person who paid attention to the hypertension nutrition diet, while the other 2 people did not pay attention. In fact, noncompliance with therapy programs is a big problem in people with hypertension. If sufferers actively participate in programs including self-monitoring of blood pressure and diet, the risk of complications such as cardiovascular, cerebrovascular, and renovascular diseases will decrease (Smeltzer and Bare, 2002).

Adherence to nutrition intake is much influenced by several factors, such as age, education level, family support, and duration of hypertension. From the various factors mentioned, research on the association of family support for hypertension control compliance has emerged and has a significant relationship. Family members are expected to be people who always support and are always ready to provide help and assistance if needed to the other family members (Friedman, 2010). Tumenggung (2013), reported that there is a significant relationship between family support and hypertension compliance of patients with hypertension. Higher family support was associated with the higher level of compliance with nutritional management in patients with hypertension. Even in the analysis of the data, Tumenggung (2013) confirmed that there were 4 respondents who did not comply with the nutritional diet and that those respondents had less family support. Based on the explanation above, the phenomenon of high rates of hypertension in Banten, especially in the Village of Kalanganyar, Lebak, still needs to be empirically proven to cause diet disobedience.

Therefore, this study aimed to examine the family support on the adherence to nutrition intake in primary hypertension patients.

\section{SUBJECTS AND METHOD}

\section{Study Design}

This was a cross sectional study conducted in the village of Kalanganyar, Lebak, Banten, Indonesia, from May to November 2019.

\section{Population dan Sample}

The population used in this study were all adults with primary hypertension in the village of Kalanganyar, Lebak, Banten. A total of 174 adults with primary hypertension was selected for this study.

\section{Study Variables}

The dependent variable was adherence to nutrition intake. The independent variables in this study were age, gender, level of education, duration of hypertension, and family support.

\section{Operational Definition of Variables}

Age was the life span of the patient as measured by the last birthday and can affect the maturity of thinking to adhere to the hypertension diet. 
Wahyudi et al./ Family support on the adherence to nutrition intake in primary hypertension

Gender was a biological characteristic that distinguishes male and female respondents and can affect personality so that the respondent adheres to or not on the hypertension diet.

Education level was the last level of formal education that has been reached by the respondent and influences the exposure of knowledge so that it influences the decision to comply with the hypertension diet.

Period of suffering from hypertension was the length of time recognized by respondents from the first time they are diagnosed with hypertension so that they have sufficient experience related to the management of hypertension and tend to adhere to the hypertension diet.

Family support was assistance given by the family in the form of emotions, appreciation, facilities, and information so that family members who suffer from hypertension can adhere to the hypertension diet.

Adherence to nutrition intake was the respondent's desire to consume hypertension diet food according to guidelines or recommendations.

\section{Data Analysis}

Data analysis in this study was carried out using univariate, bivariate, and multivariate analyzes. The use of univariate analysis was

Table 1. Sample Characteristic

\begin{tabular}{lcc}
\hline \multicolumn{1}{c}{ Variable } & n & \% \\
\hline Age & & 2.3 \\
Young adults (20-25 years) & 4 & 97.7 \\
Older adults (25-65 years) & 172 & 31.8 \\
Gender & 56 & 68.2 \\
Male & 120 & \\
Female & & 92.0 \\
Education & 162 & 8.0 \\
Low & 14 & 31.8 \\
High & 56 & 68.2 \\
Period of suffering from hypertention & 120 & 52.3 \\
Acute (<6 months) & & 47.7 \\
Family (>6 months) & 92 & \\
Poor & 84 & \\
Good & & \\
\hline
\end{tabular}

used to explain the frequency distribution of each variable. Bivariate analysis was performed using the chi-square test to analyze correlations between variables, while multivariate analysis was performed using a logistic regression test to find out which independent variables were most influential.

\section{Research Ethic}

This study employed ethical principles in its implementation, which provides initial informed consent and applies the principles of respect for human dignity, benefit, no maleficence, and justice. Ethical Clearance is obtained from the Health Research Ethics Commission of the Jakarta Veterans National Development University, with Number: B/2137/VIII/2019/KEPK.

\section{RESULTS}

1. Characteristics of Sample

A total of 174 respondents in this study had different demographic characteristics. A total of 172 adults (97.7\%) were 25-65 years old. As many as 120 adults (68.2\%) were female. While at the level of education some 162 adults (92\%) had low education. A total of 120 adults (68.2\%), has experienced chronic hypertension. A total of 92 adults (52.3\%) had lack family support. The characteristics of sample can be seen in Table 1. 
Wahyudi et al./ Family support on the adherence to nutrition intake in primary hypertension

\section{Bivariate Analysis}

Table 2 shows that gender and family support affect the adherence to nutrition intake among adults with primary hypertension.
While age, level of education, and duration of hypertension were not statistically significant with the adherence to nutrition intake among adult patients with primary hypertension.

Table 2. Bivariate Analysis

\begin{tabular}{|c|c|c|c|c|c|c|c|}
\hline \multirow{3}{*}{ Independent Variables } & \multicolumn{4}{|c|}{$\begin{array}{c}\text { Hypertension Diet } \\
\text { Compliance }\end{array}$} & \multirow{2}{*}{\multicolumn{2}{|c|}{ Total }} & \multirow{3}{*}{$\mathbf{p}$} \\
\hline & \multicolumn{2}{|c|}{ Yes } & \multicolumn{2}{|c|}{ No } & & & \\
\hline & $\mathbf{n}$ & $\%$ & $\mathbf{n}$ & $\%$ & $\mathbf{N}$ & $\%$ & \\
\hline \multicolumn{8}{|l|}{ Age } \\
\hline Young adults & 1 & 25 & 3 & 75 & 4 & 100 & \multirow{3}{*}{0.622} \\
\hline Older adults & 83 & 48.3 & 89 & 51.7 & 172 & 100 & \\
\hline \multicolumn{7}{|l|}{ Gender } & \\
\hline Female & 65 & 54.2 & 55 & 45.8 & 120 & 100 & \multirow{3}{*}{0.015} \\
\hline Male & 19 & 33.9 & 37 & 66.1 & 56 & 100 & \\
\hline \multicolumn{7}{|l|}{ Education } & \\
\hline Low & 81 & 50 & 81 & 50 & 162 & 100 & \multirow[b]{2}{*}{0.051} \\
\hline High & 3 & 21.4 & 11 & 78.6 & 14 & 100 & \\
\hline \multicolumn{8}{|l|}{ Length of hypertension } \\
\hline Acute & 33 & 58.9 & 23 & 41,1 & 56 & 100 & \multirow{2}{*}{0.052} \\
\hline Chronic & 51 & 42.5 & 69 & $57 \cdot 5$ & 120 & 100 & \\
\hline \multicolumn{8}{|l|}{ Family Support } \\
\hline Poor & 50 & 58.8 & 35 & 41.2 & 85 & 100 & \multirow{2}{*}{0.006} \\
\hline Good & 34 & 37.4 & 57 & 62.6 & 91 & 100 & \\
\hline
\end{tabular}

Table 3. Multivariate Analysis

\begin{tabular}{lcccc}
\hline \multicolumn{1}{c}{ Variables } & \multirow{2}{*}{ OR } & \multicolumn{2}{c}{$\mathbf{9 5 \% \text { CI }}$} & p \\
\cline { 3 - 4 } & & Lower Limit & Upper Limit & \\
\hline $\begin{array}{l}\text { Age } \\
\text { Young adults }\end{array}$ & 0.31 & 0.21 & 4.65 & 0.398 \\
$\begin{array}{l}\text { Older adults (1) } \\
\text { Gender }\end{array}$ & & & & \\
$\begin{array}{l}\text { Female (1) } \\
\text { Male }\end{array}$ & 2.46 & 1.19 & 5.14 & 0.016 \\
$\begin{array}{l}\text { Education } \\
\text { Low (1) }\end{array}$ & & & & \\
$\begin{array}{l}\text { High } \\
\text { Period of suffering } \\
\text { from hypertention } \\
\text { Acute (1) } \\
\text { Chronic }\end{array}$ & 2.00 & 0.43 & 9.35 & 0.375 \\
$\begin{array}{l}\text { Family Support } \\
\text { Poor } \\
\text { Good (1) }\end{array}$ & 2.41 & 1.18 & & \\
\hline
\end{tabular}

\section{Multivariate Analysis}

Table 3 shows that adherence to nutrition intake among hypertension patients was associated with female $(\mathrm{OR}=2.46 ; 95 \% \mathrm{CI}=$ 1.19 to $5.14 ; \mathrm{p}=0.016$ ), good family support $(\mathrm{OR}=2.92 ; 95 \% \mathrm{CI}=1.50$ to $5.70 ; \mathrm{p}=0.002)$, and acute hypertension $(\mathrm{OR}=2.41 ; 95 \% \mathrm{CI}=$ 1.18 to $4.94 ; \mathrm{p}=0.015)$. While older adult $(\mathrm{OR}=0.31 ; 95 \% \mathrm{CI}=0.21$ to $4.65 ; \mathrm{p}=0.398)$ and low education $(\mathrm{OR}=2.00 ; 95 \% \mathrm{CI}=0.43$ to $9.35 ; \mathrm{p}=0.375$ ) were not statistically asso- 
Wahyudi et al./ Family support on the adherence to nutrition intake in primary hypertension

ciated with adherence to nutrition intake among hypertension patients.

Older adult was 0.31 times more likely to comply with the adherence to nutrition intake than the young adult age.Female adult tend to be 2.46 times more obedient than male adult. Adults with low education were twice as likely to be obedient compared to those with high education. The acute hypertension had the potential to be 2.41 times more obedient to the adherence to nutrition intake than the chronic hypertension. The highest OR value was family support, which was 2.92. It means that adults with primary hypertension who get good family support were $\mathbf{2 . 9 2}$ times more likely to comply with the adherence nutrition intake than those who lack family support, after being controlled by factors of age, gender, level of education, and duration suffering from hypertension.

\section{DISCUSSION}

1. The effect of age on the adherence to nutrition intake

This study showed that older adult is not statistically significant in the adherence to nutrition intake $(\mathrm{OR}=0.31 ; 95 \% \mathrm{CI}=0.21$ to 4.65; $\mathrm{p}=0.398$ ).

This study is in line with study by Mahmoud (2012) and Novian (2013) which shows that age is not significantly related to hypertension diet adherence. According to Agrina, Rini and Hairitama (2011), age does not guarantee a person to have good knowledge and a positive attitude if it is not supported by factors such as education level, personal experience, or information from the surroundding environment. It can be concluded that age does not guarantee a person to be able to adhere to the hypertension diet because as he gets older the level of knowledge and attitude is not enough if he does not have experience and information in daily life.

\section{The effect of gender on the adheren- ce to nutrition intake}

This study reports that women are more likely to be obedient than men $(\mathrm{OR}=2.46$; $95 \% \mathrm{CI}=1.19$ to $5.14 ; \mathrm{p}=0.016)$ on the adherence to nutrition intake.

According to the results of other studies, when the process of undergoing various recommended therapies, indeed women tend to be more obedient to management compared to men, including hypertension diet therapy (Tibebu et al., 2017). Men can be less obedient in implementing a hypertension diet because in men there is a habit of living in a poorly healthy lifestyle such as smoking and even drinking alcoholic beverages (Bai et al., 2017).

\section{Effect of education level on the adhe- rence to nutrition intake}

This study reports that low education increased adherence to nutrition intake among hypertension patients, but it was statistically not significant. In fact, the results of this study also explain that patients with low levels of education actually tend to be more obedient than those with higher education.

This study is in line with study conducted by Miyusliani and Yunita (2011) which shows that there is no meaningful relationnship between education and patient compliance with hypertension diet. Education can be used by someone to get information, one of which is health information (Singh, Shankar and Singh, 2017). Higher education does not guarantee someone to abide by regulations such as a hypertension diet. Education owned by someone may not be able to provide compliance or satisfaction in choosing foods that are good for their health (Miyusliani and Yunita, 2011; Zajacova and Lawrence, 2018).

4. The effect of length of hypertension on the adherence to nutrition intake

This study reports that acute hypertension increased the adherence to nutrition intake. 
Wahyudi et al./ Family support on the adherence to nutrition intake in primary hypertension

This study is in line with study conducted by Adisa et al. (2018) which shows that there is a long-standing relationship of suffering from hypertension with adherence in undergoing hypertension therapy. Long suffer from hypertension means that the longer a person suffers from hypertension, the lower the level of compliance, this is because most sufferers often forget and feel bored to adhere to therapy (Adisa et al., 2018; Berisa and Dedefo, 2018). If adherence is not improved and strived to be consistent, then high blood pressure for a long time can damage the endothelium and accelerate the occurrence of atherosclerosis and various other complication (Prasetyorini and Prawesti, 2012).

\section{The effect of family support on the adherence to nutrition intake}

This study reports that good family support $(\mathrm{OR}=2.92 ; 95 \% \mathrm{CI}=1.50$ to $5.70 ; \mathrm{p}=0.002)$ is statistically associated with the adherence to nutrition intake.

This study is in accordance with some of the results of previous studies which revealed that there was a relationship between family support and dietary compliance and other treatments in hypertension patients (Barreto and Marcon, 2014; Tibebu et al., 2017; Ashoorkhani et al., 2018; Ayodapo et al., 2018).

This study also strengthened by study conducted by Tarigan et al. (2018) on "the effect of knowledge, attitudes, and family support on the hypertension diet" which also found that there was a significant influence between family support and the hypertension diet.

Management of hypertension can be done in various ways, one of them with an adherence to nutrition intake. The adherence to nutrition intake aims to lower blood pressure and maintain blood pressure to remain normal, and reduce risk factors for hypertension (Nita and Oktavia, 2018). Adherence to nutrition intake is considered as a hassle and unpleasant because sufferers must avoid foods they like, such as salt, salted fish, red meat, and innards. According to Stein et al. (1998) in Niven (2000), factors that influence the compliance of hypertension sufferers in implementing a hypertension diet are an understanding of hypertension diet instructtions, quality of interaction with others, beliefs, attitudes, personality of hypertension sufferers, and family social support.

Family support in the hypertension diet becomes the duty of other family members to care for family members who suffer from hypertension. Support from the family is needed in the treatment of hypertension sufferers and is an important factor in helping individuals solve problems (Mahadewi et al., 2017).

Forms of family support on the hypertension diet include emotional support, appreciation support, informational support, and instrumental support (Friedman, 2010). Emotional support can be in the form of providing special food to patients with hypertension that is different from the food of other family members in the hope that hypertension sufferers do not experience hypertension recurrence, other than that the family can reprimand if hypertension sufferers eat fried foods, salted fish, and coconut milk. Appreciation support can be in the form of giving compliments to patients with hypertension who are compliant in implementing the adherence to nutrition intake. Informational support can be in the form of information to patients with hypertension about the benefits of not eating fried foods, salted fish, and fatty foods. Instrumental support can be in the form of food modification or providing care to patients with hypertension that leads to a hypertension diet (Nisfianiet al. 2014).

This study conclude that family support is needed in terms of adherence to nutrition intake. Family support can make hypertension sufferers feel cared for and valued. Family awareness in providing support to fa- 
Wahyudi et al./ Family support on the adherence to nutrition intake in primary hypertension

mily members who suffer from hypertension causes hypertension sufferers to comply with the hypertension diet so that no further complications arise. The family can provide support in the form of giving a reprimand if the hypertension sufferer does not implement a hypertension diet, giving compliments if he has complied to implement a hypertension diet, giving information about foods recommended for the hypertension diet, and making food modifications so that hypertension sufferers do not feel bored with the hypertension diet that they are on.

\section{AUTHOR CONTRIBUTION}

Chandra Tri Wahyudi formulated the concepts, collected the data, and processed study data. Arief Wahyudi Jadmiko and Ritanti contributed in designing research methodlogies, collected the data, analyzed the data results and interpreted them.

\section{CONFLICT OF INTEREST}

There is no conflict of interest in this study.

\section{FUNDING AND SPONSORSHIP}

The funding for this study was from the UPN Veteran Jakarta Institute for Research and Community Service.

\section{ACKNOWLEDGEMENT}

The researcher would like to thank all the respondents, the village administration, and the Kalanganyar Regional Health Center, Lebak, Banten for providing the researchers with the opportunity to conduct this study.

\section{REFERENCE}

Adisa R, Ilesanmi OA, Fakeye TO (2018). Treatment adherence and blood pressure outcome among hypertension outpatients in two tertiary hospitals in Sokoto, Northwestern Nigeria. BMC Cardiovasc Disord, 18(1): 1-10. https://doi.org/10.1186/s12872-018-0934-x
Agrina RSS, Hairitama R (2011). Kepatuhan lansia penderita hipertensi dalam pemenuhan diet hipertensi. Jurnal Sorot, 6(1): 46-53. https://dx.doi.org/10.31258/sorot.6.1.2001

Ashoorkhani M, Majdzadeh R, Gholami J, Eftekhar H, Bozorgi A (2018). Understanding non-adherence to treatment in hypertension: A qualitative study. Int J Community Based Nurs Midwifery, 6(4): 314-323. Retrieved from https://www.ncbi.nlm.nih.gov/pubmed/30465 004

Ayodapo AO, Monsudi KF, Omosanya OE, Elegbede OT (2018). Family Functioning and Adherence to Medication: A Study of Hypertensive in a Tertiary Hospital, South Western Nigeria. CHRISMED J Health Res, 5(3): 197-202. Retrieved from http://www.cjhr.org/article.asp?issn $=2348-3334$;year $=201-$ 8 ; volume $=5 ;$ issue $=3$; spage $=197$; epage $=202$; aulast $=$ Ayodapo

Bai G, Zhang J, Zhao C, Wang Y, Qi Y, Zhang $B$ (2017). Adherence to a healthy lifestyle and a DASH-style diet and risk of hypertension in Chinese individuals. Hypertension Research, 40(2): 196202. https://doi.org/10.1038/hr.2016.119

Barreto MS, Marcon SS (2014). Patient perspectives on family participation in the treatment of hypertension. Texto \& Contexto-Enfermagem, 23(1): 38-46. https://doi.org/10.1590/So104-07072014000100005

Berisa HD, Dedefo MG (2018). Non-Adherence Related Factors to Antihypertensive Medications among Hypertensive Patients on Follow up at Nedjo General Hospital in West Ethiopia. Open Public Health J, 11: 62-71. http://dx.doi.org/10.2174/1874944501811010062 
Wahyudi et al./ Family support on the adherence to nutrition intake in primary hypertension

Friedman MM (2010). Buku Ajar Keperawatan Keluarga: Riset, Teori, dan Praktek ( $5^{\text {th }}$ ed.). Jakarta: EGC.

Mahadewi, IGAM, Suniyadewi NW, Mudia N (2017). Hubungan Dukungan Keluarga Dengan Pola Hidup Sehat Hipertensi Pada Keluarga. Bali Medika Jurnal, 4(2). https://doi.org/10.36376/bmj.v4i2.1

Mahmoud MIH (2012). Compliance with treatment of patients with hypertension in Almadinah Almunawwarah: A community-based study. Journal of Taibah University Medical Sciences, 7(2): 9298. https://doi.org/10.1016/j.jtumed.2012.11.004

Ministry of Health (2018). Laporan hasil riset kesehatan dasar (Riskesdas) Indonesia tahun 2018. Riset Kesehatan Dasar 2018. Jakarta: Badan Penelitian dan Pengembangan Kesehatan Kementerian Kesehatan Republik Indonesia.

Miyusliani S, Yunita J (2011). Faktor resiko yang berpengaruh terhadap kepatuhan diet hipertensi. jurnal kesehatan komunitas, 1(3): 163-169. https://doi.org/10.25311/jkk.vol1.iss3.21

Nisfiani AD, Irdawati, Kartinah (2014). Hubungan dukungan keluarga dengan kepatuhan diit hipertensi pada lanjut usia di Desa Begajah Kecamatan Sukoharjo, Kabupaten Sukoharjo. Surakarta: Universitas Muhammadiyah Surakarta.

Nita Y, Oktavia D (2018). Hubungan dukungan keluarga dengan kepatuhan diet pasien hipertensi di Puskesmas Payung Sekaki Pekanbaru Tahun 2017. Jurnal Ilmu Kesehatan, 6(1). Retrieved from http://journals.umkt.ac.id/index.php/j $\mathrm{ik} /$ article/download/103/63

Niven N (2000). Psikologi kesehatan: Pengantar untuk perawat \& profesional kesehatan lain. Jakarta: EGC.
Novian A (2013). Kepatuhan Diit Pasien Hipertensi. Jurnal Kesehatan Masyarakat Universitas Negeri Semarang, 9(1). Retrieved from https://journal.unnes.ac.id/nju/index.php/kemas/article/vie $\mathrm{w} / 2836 / 2889$

Prasetyorini HT, Prawesti D (2012). Stres pada penyakit terhadap kejadian komplikasi Hipertensi pada pasien Hipertensi. Jurnal Stikes, 5(1). Retrieved from https://media.neliti.com/media/publications/210184-none.pdf

Rosyid FN, Efendi N (2011). Hubungan kepatuhan diet rendah garam dan terjadinya kekambuhan pada pasien hipertensi di wilayah Puskesmas Pasongsongan Kabupaten Sumenep Madura. Proseding Soft Skill and Character Building, 713. Surabaya: Universitas Muhammadiyah Surabaya.

Singh S, Shankar R, Singh GP (2017). Prevalence and Associated risk factors of hypertension: A cross-sectional study in Urban Varanasi. International Journal of Hypertension, 2017. https://doi.org/10.1155/2017/5491838

Smeltzer SC, Bare BG (2002). Buku Ajar Keperawatan Medikal Bedah ( $8^{\text {th }}$ ed.). Jakarta: EGC.

Tarigan AR, Lubis Z, Syarifah (2018). Pengaruh pengetahuan, sikap dan dukungan keluarga terhadap diet hipertensi di Desa Hulu Kecamatan Pancur Batu Tahun 2016. Jurnal Kesehatan, 11(1): 9-17. https://doi.org/10.24252/kesehatan.v11i1.5107

Tibebu A, Mengistu D, Negesa L (2017). Adherence to recommended lifestyle modifications and factors associated for hypertensive patients attending chronic follow-up units of selected public hospitals in Addis Ababa, Ethiopia. Patient Preference and Adherence, 11: 323330. https://doi.org/10.2147/PPA.S126382 
Wahyudi et al./ Family support on the adherence to nutrition intake in primary hypertension

Tumenggung I. (2013). Hubungan Dukungan sosial keluarga dengan kepatuhan diet pasien hipertensi di RSUD Toto Kabila Kabupaten Bone Bolango. Jurnal Health and Sport Universitas Negeri Gorontalo, 7(1). Retrieved from http://ejurnal.ung.ac.id/index.php/JHS/articl e/view/1085

WHO (2015). Hypertension. World Health Organization. Retrieved from https://- www.who.int/news-room/fact-sheets/detail/hypertension

Zajacova A, Lawrence EM (2018). The relationship between education and health: reducing disparities through a contextual approach. Annu Rev Public Health, 1(39): 273-289. https://doi.org/10.1146/annurev-publhealth-031816-044628 